Original Article

\title{
GENE FLOW FROM WILD TO MANAGED COLONIES IN THE STINGLESS BEE SCAPTOTRIGONA MEXICANA AND AN UPDATE ON ITS MATING
}

\section{FREQUENCY}

\author{
Erik de Jesús Solórzano-Gordillo ${ }^{1}$ \\ James C. Nieh² \\ Leopoldo Cruz-López ${ }^{1}$ \\ Daniel Sánchez ${ }^{1}$ \\ ${ }^{1}$ El Colegio de la Frontera Sur - Unidad Tapachula, Mexico \\ 2Division of Biological Sciences, Section of Ecology, Behavior and Evolution, \\ University of California - Campus San Diego, United States \\ Received: 16 March 2021; accepted: 14 October 2021 \\ *corresponding author: dsanchez@ecosur.mx
}

\begin{abstract}
Researchers have hypothesized that wild stingless bee colonies are a repository of genes for managed populations via the mating of managed virgin queens with males from wild colonies. We tested this hypothesis with the stingless bee, Scaptotrigona mexicana, a culturally important species in the study region. Each of ten colonies were split into two colonies and placed in a meliponary, which resulted in ten queen-right mother colonies and ten queen-less daughter colonies. We allowed daughter colonies to produce gynes, which then naturally mated with males of unknown origins. Six months later, five thirdinstar larvae from each colony were genotyped at six microsatellite loci. Four new alleles (12\% of 33 alleles) were found in daughter colonies that were not present in any other mother colony. The Fst index showed no overall significant differences between mother and daughter colonies, indicating that they belonged to the same population despite the new alleles. Interestingly, nine queens were estimated to be polyandrous, with an average mating frequency of 1.3, unlike previous reports for this species. These results have implications for the fitness of managed stingless bee colonies and suggest that a better understanding of how gene flow is affected by human management practices would be beneficial.
\end{abstract}

Keywords: eusocial bees, genetic flow, male stingless bee congregation, meliponine

\section{INTRODUCTION}

Stingless bees (Apidae, Meliponini), a group of eusocial Hymenoptera, are exclusively tropical (Michener, 2013) and important pollinators of many flowering plants, both domesticated and wild (Heard, 1999). Some meliponine species have been semi-domesticated to provide honey and, more importantly, pollination services (Kwapong et al., 2010). A key aspect of this semi-domestication has been the development of colony splitting and propagation techniques (Aidoo, 2020). Meliponaries, where managed stingless bee colonies are established, can have relatively high relatedness and correspondingly decreased genetic diversity since meliponicul- ture leads to multiple daughter colonies arising from relatively few mother colonies.

Stingless bee colonies naturally reproduce when reproductive females (gyne) mate with males gathered in congregations that typically occur in close vicinity to the colony from which the virgin queen emerges (Wille, 1983). In Melipona favosa, for example, young queens are attracted to males congregating twelve meters from the colony (Sommeijer \& de Bruijn, 1995). However, these congregations might include males from colonies located at more distant locations: males of Tetragonisca angustula are known to disperse from a few meters up to 2.25 $\mathrm{km}$ from their colony, thus reducing the probability of inbreeding (dos Santos et al., 2016). 


\section{_ SOLÍfRZANO-60RDIIL Et Hl. _ Polyandry and gene flow in a stingless bee}

Once males have chosen a spot and aggregate, they wait for the virgin queens on a perch that includes the structures that shelter meliponaries (and are sometimes made of metal), near the entrance of the colony from which the gyne will emerge, or on the leaves and branches of surrounding trees (López \& Kraus, 2009; dos Santos et al., 2014). Male congregations form at specific times of the day, during which the queen is exposed for mating. Such congregations might decrease predation since males of some meliponine species that fly alone were attacked more often than males in groups (Cortopassi-Laurino, 2007). Interestingly, some congregations consist of males of more than one species (dos Santos et al., 2015), which indicates that drone congregations could have other roles besides reproduction and protection.

As with other meliponine species, there is an additional close relationship between mother and daughter colonies of the stingless bee Scaptotrigona mexicana, because materials such as wax and cerumen are moved from a mother colony to build new daughter colonies, which are commonly built nearby (Wille, 1983). In principle, such proximity among related colonies might promote inbreeding, and studies have shown that the gynes of some stingless bee species such as Melipona mondury, M. beecheii, Lestrimellitta limao, Nannotrigona perilampoides, Paratrigona subnuda, S. postica, and S. depilis can mate up to six times (Paxton et al., 1999a; Paxton, 2000) but others, such as Trigona fulviventris, just once (Green \& Oldroyd, 2002; Palmer et al., 2002; Vollet-Neto et al., 2018; Vollet-Neto et al., 2019). Veiga et al. (2021) suggested that the quality of the plug formed by the male genitalia remaining in the mated queen is involved because such plugs that are difficult for the queen to remove and thereby increase the probability of single mating. There is also a trade off between single and multiple mating strategies. Monandry is defined as a queen mating only once and is considered as a precondition for eusociality because it maximizes genetic relatedness between colony members and thus colony cohesion (Hughes et al., 2008; Jaffé, 2014). In contrast, polyandry (multiple mating) decreases the frequency of diploid males, reduces parasitism, and increases genetic diversity (Baer \& Schmid-Hempel, 1999; Tarpy \& Page Jr, 2001; Borges et al., 2010; Jaffé, 2014). Thus, whether colonies have single or multiple patrilines depend upon the species, the efficacy of mating plugs and other factors still to be revealed (Peters et al., 1999; Veiga et al., 2021).

In prior studies with S. mexicana, Kraus et al. (2008) found that the majority of patrilines in managed colonies apparently originated from wild colonies and not from managed ones within the same meliponaries. Cameron et al. (2004) similarly showed that wild aggregations of Trigona collina colonies were also highly outbred. Such genetic diversity due to mating with unrelated males should have multiple benefits since inbreeding can reduce fitness (Whitehorn et al., 2009), and even lead populations into extinction vortexes via a complementary sex determination pathway in which females that are homozygous at the csd locus become sterile diploid males (Vollet-Neto et al., 2015). In honey bees, outbreeding also improves individual bee immune responses to parasites (Simone-Finstrom et al., 2016). Thus, mating between genetically unrelated individuals brings multiple advantages (Fuchs \& Moritz, 1999; Schlüns et al., 2005).

To increase the number of colonies in a meliponary via artificial colony fission, a colony in good condition is split into two colonies at the correct time of year. One colony keeps the queen (the mother colony) while the other colony (the daughter colony) is transferred to a new hive box with brood, royal gyne cells, workers, pollen, and honey pots, resembling (in part) the natural process of colony reproduction. The virgin queen emerges from the daughter colony and then mates at a nearby male congregation (Guzmán Díaz et al., 2004). This illustrates the importance of wild stingless bee populations for maintaining the genetic variability and thereby the health of managed colonies (Moritz, 2002). In turn, managed stingless bee colonies, which are often transported from adjacent areas, provide males that help increase the genetic diversity of 
wild colonies by introducing alleles that might be absent or occur at low frequencies (CortopassiLaurino et al., 2006). Finally, the management of stingless bees has deep and ancient links with indigenous, cultural and economic practices (Cortopassi-Laurino et al., 2006; Quezada-Euán, 2018; Escareño et al., 2019). Thus, meliponaries have the potential to help conserve wild populations, enhance the pollination services that they provide, and preserve the rich cultural history of indigenous peoples (Hill et al., 2019).

Despite evidence for the high probability of mating between wild and managed individuals in stingless bees, no study has demonstrated experimentally that new alleles actually enter the genetic pool of managed colonies via the mating of managed queens with wild male stingless bees. We therefore sought to test this hypothesis and chose $S$. mexicana as our biological model, because it is commonly used in meliponaries, has been extensively investigated (Guzmán Díaz et al., 2004; Sánchez et al., 2016; Sánchez-Guillén et al., 2018), is relatively common as wild colonies in the study area (Ayala, 1999), and has a cultural and economic role in local communities. Moreover, since some stingless bee species once thought to be singly mated, are now known to be multiply mated, we also investigated the mating frequency in S. mexicana.

\section{MATERIAL AND METHODS}

\section{Study site and biological material}

Ten managed $S$. mexicana colonies from a meliponary in the city of Tuxtla Chico, Chiapas, Mexico, were chosen for the experiments. The splitting and propagating of six colonies occurred in February 2017 and of the remaining four in January 2019. All daughter and mother colonies were maintained at the same meliponary. Prior to splitting, all colonies were carefully inspected by an experienced beekeeper to certify their good health and suitability for colony reproduction.

\section{Colony reproduction}

Once colonies were ready for the procedure, ten identical wood boxes $(22 \times 22 \times 40 \mathrm{~cm})$ were prepared, and colony division was carried out as described by Guzmán Díaz et al. (2004). Essentially, the queen was retained in her old colony (mother colonies, M1-M10) and half of the workers, food pots, and combs were placed in another wood box to form new colonies (daughter colonies, D1-D10). It normally takes one to two months for virgin queens to emerge and breed (Guzmán Díaz et al., 2004). Each mother and daughter colony was labeled and maintained in the same meliponary. Queens from the mother colonies were painted on their thoraces with a POSCA PC5M marker to ensure that they were the original queens, not replacements, and then returned to their colonies. We allowed the virgin queen from the daughter colonies to mate freely. The queens of these daughter colonies were also distinctively paintmarked on their thoraces once they began laying eggs.

\section{Bee sampling and genotyping}

Exactly six months after splitting the colonies, we checked that all of them had painted queens. After confirming this, we collected from the colonies third instar larvae (which should be unambiguously genetically related to the queen) given that all larvae transferred from the mother colonies would have completed their development months beforehand. Five specimens per colony were obtained from the bottom combs in which older instar larvae are commonly found and stored in 95\% reagent grade ethanol in labeled vials until analysis. We sampled five specimens because $S$. mexicana queens are putatively singly mated (Palmer et al., 2002), and thus this sample size should be sufficient for us to detect the majority of distinctive alleles in the colony.

We extracted DNA from the bees after first rinsing off the alcohol with $100 \mathrm{ml}$ of doubledistilled water for $30 \mathrm{~min}$ at room temperature. DNA was extracted with the HotSHOT method (Truett et al., 2000). Single locus PCR protocols with a final reaction volume of $5 \mu \mathrm{L}$ (Solórzano-Gordillo et al., 2015) were used to genotype all specimens at six microsatellite loci: 


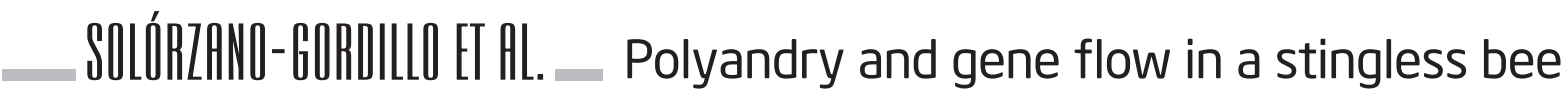

B124 developed for Bombus terrestris (Estoup et al., 1993), T7-5, T1-35, T8-40, and T4-171 for S. postica (Paxton et al., 1999b), and Tc3-302 for Trigona carbonaria (Green et al., 2001). Microsatellite fragments were separated with a semiautomated LI-COR 4200 slab-gel sequencer (6\% denaturing polyacrylamide gels), and fragment size was determined with SAGA MX software (LI-COR Inc., US). Forward oligos were tagged with an M13 (-29) sequence, which served as a priming site for a M13 (-29) primer tagged with IRDYE800 (Schuelke, 2000). To estimate amplification errors, $10 \%$ of specimens were reamplified at all loci. However, all reamplifications yielded identical results. Because stingless bees have a haplo-diploid sex determination system, any homozygous individual was clearly male and was discarded since we were focused on females.

\section{Descriptive and statistical analysis}

First, we conducted descriptive genetic analyses of each colony. We then ran an AMOVA (Michalakis \& Excoffier, 1996) using Genodive v2.0b27 (Meirmans \& Van Tienderen, 2004) to determine any genetic differences between mother (M) and daughter (D) colonies that could arise due to mating with wild males. A power

Table 1.

Patrilines (Patril.) estimated in each colony, number of new alelles found in daughter colonies not found in any mother colony, and effective mating frequency (me), which was calculated as in Starr (1984): $m e=1 / \Sigma y_{i}^{2}$, where $y_{i}$ is the proportion of offsprings contributing to patriline $i$ in a colony. Letters M or D in the column "Colony", as in M1 and D1, refer to "Mother" and "Daughter" colony, respectively. Equal numbers in the column "Colony" indicate the mother-daughter dyad.

\begin{tabular}{cccc}
\hline Colony & Patril. & $\begin{array}{c}\text { New } \\
\text { alleles }\end{array}$ & me \\
\hline M1 & 1 & 0 & 1 \\
D1 & 1 & 0 & 1 \\
M2 & 3 & 0 & 1.69 \\
D2 & 4 & 1 & 2.56 \\
M3 & 3 & 0 & 1.92 \\
D3 & 1 & 1 & 1 \\
M4 & 1 & 0 & 1 \\
D4 & 1 & 1 & 1 \\
M5 & 2 & 0 & 2 \\
D5 & 1 & 0 & 1 \\
M6 & 1 & 0 & 1 \\
D6 & 1 & 0 & 1 \\
M7 & 3 & 0 & 1.92 \\
D7 & 1 & 0 & 1 \\
M8 & 1 & 0 & 1 \\
D8 & 2 & 1 & 1.6 \\
M9 & 1 & 0 & 1 \\
D9 & 3 & 0 & 1.6 \\
M10 & 5 & 0 & 1.47 \\
D10 & 5 & 0 & 2.53 \\
Mean ( \pm SD & $2.05 \pm 1.39$ & & $1.41 \pm 0.53$ \\
\hline
\end{tabular}


analysis was run using POWSIM v4.1 program as indicated by Ryman \& Palm (2006). Finally, we used Matesoft v1.0 to determine the number of patrilines and the effective mating frequency in our colonies (Moilanen et al., 2004; Starr, 1984).

\section{RESULTS}

One hundred larvae from twenty colonies were fully genotyped at six loci, and, since at least one locus of each larva was heterozygous, none were considered male (Supplementary Material 1). The relative number of alleles between mother and daughter colonies is shown in Supplementary Material 2. Four new alleles were observed in daughter colonies, and thus clearly indicate that the queens of these colonies had mated with unrelated males (Supplementary Material 3). After 9999 permutations, the AMOVA (infinite mutation model) showed that there were no genetically significant differences between mother and daughter colonies, so they could be considered as coming from a single population $\left(F_{s t}=0.003 ; p=0.7\right.$; statistical power of the analysis was 0.57 after 1000 runs, setting $F_{s t}=0.003$ as the threshold value). Surprisingly, we found evidence for polyandry, and nine colonies had multiple mated queens, with up to five matings per queen (Tab. 1).

\section{DISCUSSION}

We tested the contribution of wild populations to the genetic pool of a managed meliponary by generating daughter colonies that could freely mate with wild and managed male stingless bees. Overall, queens mated with males of similar genotypes to the ones present at their meliponary, suggesting that the diversity of colonies established at a meliponary plays a strong role in its genetic diversity and, by association, fitness. However, the detection of four new alleles (12\% of 33 alleles total) in daughter colonies that were not found in any mother colony, demonstrates the introduction of genetic material from wild male stingless bees. Moreover, multiple mated queens were detected, and thus polyandry in this species might be more frequent than previously stated. Our data therefore suggest that $S$. mexicana is not singly mated, and that wild S. mexicana populations contribute to a limited degree to the genetic pool of managed meliponaries.

In $S$. mexicana, male stingless bee congregations at or near meliponaries vary considerably in size but consist of $1850 \pm 1026$ (mean \pm 1 SD) males, likely from both wild and managed colonies (López \& Kraus, 2009). Daughter colony gynes could therefore have mated with males from mother colonies, which could account for why most daughter colonies did not show new alleles. Another possibility is that our mother colonies had been under management from five to ten years, and thus genetic introgression between wild and managed populations had occurred such that managed and wild colonies were quite similar. This process could be accelerated because colonies naturally requeen and mate with wild males (natural gene flow) and given that beekeepers capture wild colonies and bring them to the meliponary (human-driven genetic flow). In fact, all our colonies came from the landscape surrounding the meliponary. Human-mediated and natural gene flow in stingless bees has implications for conservation that should be better understood.

Genetic analyses of male stingless bees in congregations near colonies from which gynes emerge demonstrate that these typically differ from male stingless bees raised in a S. mexicana meliponary (Mueller et al., 2012). Thus, one would expect a higher probability of gynes mating with a non-related male. In our case, there was potentially a relative lack of male stingless bees from wild colonies near our site (leading to the small amount of genetic inflow that we observed), although this seems unlikely based upon the relatively high density of wild S. mexicana colonies that have been found near our site (Kraus et al., 2008). Another possibility is that our study was conducted after Mueller et al. (2012), and sufficient time may have passed to allow feral and managed populations to become more genetically similar so that mating between wild males and managed gynes would be more difficult to detect. 


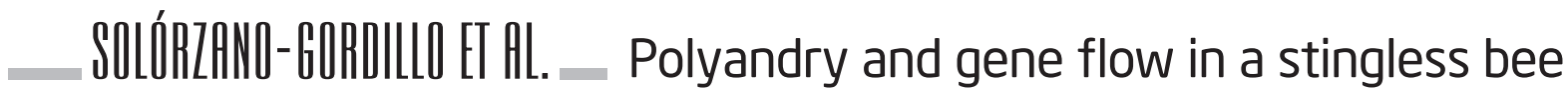

One of our key assumptions is that the wild population will have different alleles. Unfortunately, we do not know allele frequencies in the wild population because of the difficulty of finding all nearby wild colonies and sampling bees from them. Collecting males from nearby male congregations is more feasible, but again raises the issue of identifying males from wild versus managed colonies. Because this constrains our interpretations, we view this study as exploratory, with further research needed, perhaps using bee colonies transported from much greater distances and thereby with a higher likelihood of different alleles. However, this raises other problems, such as influencing the natural genetic diversity of nearby wild colonies and potentially introducing new pathogens or parasites. Detailed, landscape level studies of stingless bee genetic diversity and pathogen and parasite loads would be helpful for developing sustainable management practices that involve the transport of colonies across landscapes.

Seasonality and management effects could also account for differences in the relative proportion of wild to managed males. The production of brood and reproductives varies seasonally in stingless bees and connects with seasonal variation in food availability (Grüter, 2020). For example, in our study, queen mating occurred earlier in the year but the evaluation of male congregations by Mueller et al. (2012) occurred later in the year, during May and June. If wild colonies were just emerging from a food dearth during the early part of the year, one might expect them to produce fewer males as compared to managed colonies. Later in the year, when food is more abundant, wild colonies could produce more males, accounting for their increased frequency, as seen in Mueller et al. (2012). However, our colonies were only managed to the extent of being housed in wood boxes. Managed colonies did not receive supplemental food, and thus their production of reproductives should be similar to wild colonies nearby. In some cases, beekeepers may feed their managed colonies (Quezada-Euán et al., 2001) and thereby potentially encourage inbreeding by increasing the ratio of managed to wild males. This would be interesting to study in the future. Finally, we conducted this study in two separate years, 2017 and 2019. Although this may have contributed to variation in the production and ratio of managed to wild males between these years, we did not find any evidence for substantial variation between these years (based upon our AMOVA), and replication over more than one year in a field study is generally recommended (Lemoine et al., 2016).

To our surprise, nine out of twenty colonies had multiple-mated queens, which contradicts previous results by Palmer et al. (2002). Possibly our greater sample size ( $\mathrm{N}=20$ vs. $\mathrm{N}=5$ in Palmer's work) allowed us to detect more patrilines. Another explanation is that there is variation in mating frequency among populations, as is known to occur in other highly social corbiculate bees. Within the highly polyandrous Apis dorsata, queens can mate with 13 to 39 males (Oldroyd et al., 1996). Similarly, in Melipona mondury, seven out of nine queens had a high degree of polyandry (2-7 patrilines) (Viana et al., 2015). The stingless bee $S$. postica has been found to be multiple-mated in some colonies (Paxton et al., 1999a), and singly mated in others (Peters et al., 1999). More recently, S. depilis changed its status from being singly mated to multiply mated (Vollet-Neto et al., 2019). Our finding suggests that detailed surveys of many colonies in multiple regions should be performed to confirm the number of matings and to investigate factors that might explain such variation. Given the size of typical male stingless bee congregations in S. mexicana, a lack of partners would not account for single mating, raising the possibility that other factors, including potential local adaptations that modify the quality of males, prevalence of diseases, and the availability of resources, play roles in queens being singly or multiply mated.

Our results suggest that wild stingless bee populations can contribute to the genetic diversity of managed populations to a limited degree. These data show the importance of continuing to evaluate the contributions of wild and managed stingless bee populations and examining the 
factors that influence the genetic diversity of male stingless bee congregations. Our data also indicate that the genetic diversity of a meliponary plays a strong role in maintaining its diversity and its associated fitness, given that queens from managed colonies largely mated with males from managed colonies. Managed colonies may also provide alleles to the wild population, but we think that this contribution would be minor given that colonies of these species are typically not moved far from their original, natural location. Nonetheless, the artificial propagation of managed colonies may result in an increase in some alleles that are rare but that then become strong competitors of naturally abundant alleles. This hypothesis remains to be tested. Finally, increasing evidence for multiple mating in stingless bee species that were once considered singly mated might be due to increased testing and sampling of different populations. An intriguing question is whether polygyny is influenced by climate change or other anthropogenic factors. Both possibilities deserve future investigation.

Authors' contributions: All authors have contributed to this manuscript and agree to submit it the way it was written. Material preparation, data collection and analysis were performed by Erik de Jesus Solórzano-Gordillo.

\section{ACKNOWLEDGEMENTS}

We deeply appreciate the help provided by Augusto Campollo-Ovalle, Agustín Méndez and Miguel Guzmán during the field and laboratory work. We also acknowledge the financial support from SADER (Secretaría de Agricultura y Desarrollo Rural)-CONACYT (El Consejo Nacional de Ciencia y Tecnología) project number 291333. The first author was also supported with a scholarship from CONACYT.

\section{REFERENCES}

Aidoo, K. (2020). Management of stingless bee colonies for crop pollination. In Towards sustainable crop pollination services: Measures at field, farm and landscape scales. Rome. (pp. 69-79). Rome: Food and Agriculture Organization of the United Nations.

Ayala, R. (1999). Revisión de las abejas sin aguijón de México (Hymenoptera: Apidae: Meliponini). Folia Entomológica Mexicana, 106, 1-123.

Baer, B., \& Schmid-Hempel, P. (1999). Experimental variation in polyandry affects parasite loads and fitness in a bumble-bee. Nature, 3976715), 151154.

Borges, A. A., Campos, L. A. d. O., Salomão, T. M. F." Tavares, M. G. (2010). Genetic variability in five populations of Partamona helleri (Hymenoptera, Apidae) from Minas Gerais state, Brazil. Genetics and Molecular Biology, 33(4), 774-780.

Cameron, E. C., Franck, P., Oldroyd, B. P. (2004). Genetic structure of nest aggregations and drone congregations of the southeast Asian stingless bee Trigona collina. Molecular Ecology, 13(8), 2357-2364. DOl: 10.1111/j.1365-294X.2004.02194.x

Cortopassi-Laurino, M. (2007). Drone congregations in Meliponini: what do they tell us? Bioscience Journal, 23, 153-160.

Cortopassi-Laurino, M., Imperatriz-Fonseca, V. L., Roubik, D. W., Dollin, A., Heard, T., Aguilar, I., ... NogueiraNeto, P. (2006). Global meliponiculture: challenges and opportunities. Apidologie, 372), 275-292. DOl: 10.1051/apido:2006027

dos Santos, C. F., Ferreira-Caliman, M. I., Nascimento, F. S. (2015). An alien in the group: eusocial male bees sharing nonspecific reproductive aggregations. Journal of Insect Science, 15(1), 1-7. DOl: 10.1093/ jisesa/iev107

dos Santos, C. F., Imperatriz-Fonseca, V. L., Arias, M. C. (2016). Relatedness and dispersal distance of eusocial bee males on mating swarms. Entomological Science, 19(3), 245-254.

dos Santos, C. F., Menezes, C., Vollet-Neto, A., Imperatriz-Fonseca, V. L. (2014). Congregation sites and sleeping roost of male stingless bees 


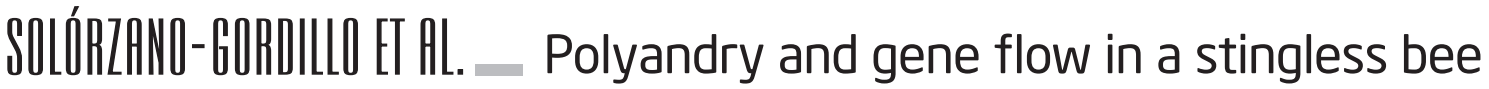

(Hymenoptera: Apidae: Meliponini). Sociobiology, $67(1), 115-118$

Escareño, F. C., Echazarreta, C. M., Gusmán-Nóvoa, E., Macías-Macías, J. O. (2019). Traditional knowledge and potential use of stingless bees (Hymenoptera: Meliponinae) in the Manantlan Sierra, Jalisco, Mexico. Sociobiology, 66(1), 120-125. DOl: 10.13102/ sociobiology.v66i1.3396

Estoup, A., Solignac, M., Harry, M., Cornuet, J. M. (1993). Characterization of (GT) $n$ and (CT)n microsatellites in two insect species: Apis mellifera and Bombus terrestris. Nucleic Acids Research, 27(6), 1427-1431. DOl: 10.1093/nar/21.6.1427

Fuchs, S., \& Moritz, R. F. A. (1999). Evolution of extreme polyandry in the honeybee Apis mellifera L. Behavioral Ecology and Sociobiology, 45(3-4), 269275. DOl: 10.1007/s002650050561

Green, C. L., Franck, P." Oldroyd, B. P. (2001). Characterization of microsatellite loci for Trigona carbonaria, a stingless bee endemic to Australia. Molecular Ecology Notes, 7(1-2), 89-92. DOl: 10.1046/j.1471-8278 2001.00041.x

Green, C. L., \& Oldroyd, B. (2002). Queen mating frequency and maternity of males in the stingless bee Trigona carbonaria Smith. Insectes Sociaux, 49, 196-202. DOl: 10.1007/s00040-002-8301-3

Grüter, C. (2020). Stingless Bees: An Overview. Stingless Bees, 1-42. DOl: 10.1007/978-3-03060090-7_1

Guzmán Díaz, M. Á., Rabanales Rincón, M., Vandame, R. (2004). Manejo y conservación de abejas nativas sin aguijón (Apidae: Meliponini). México: El Colegio de la Frontera Sur.

Heard, T. A. (1999). The role of stingless bees in crop pollination. Annual Review of Entomology, 44, 183206. DOl: 10.1146/annurev.ento.44.1.183

Hill, R., Nates-Parra, G., Quezada-Euán, J. J. G., Buchori, D., LeBuhn, G., Maués, M. M., ... Roué, M. (2019). Biocultural approaches to pollinator conservation.
Nature Sustainability, 2(3), 214-222. D0l: 10.1038/ s41893-019-0279-1

Hughes, W. O. H., Oldroyd, B. P., Beekman, M., Ratnieks, F. L. W. (2008). Ancestral monogamy shows kin selection is key to the evolution of eusociality. Science, 3205880), 1213-1216.

Jaffé, R. (2014). An updated guide to study polyandry in social insects. Sociobiology, 67(1), 1-8.

Kraus, F., Weinhold, S., Moritz, R. (2008). Genetic structure of drone congregations of the stingless bee Scaptotrigona mexicana. Insectes Sociaux, 55(1), 22-27. DOl: 10.1007/s00040-007-0966-1

Kwapong, P." Aidoo, K., Combey, R." Karikari, A. (2010). Stingless bees. Importance, management and utilization. A training manual for stingless beekeeping. Ghana: Unimax MacMillan.

Lemoine, N.P., Hoffman, A., Felton, A.J.,Baur, L,, Chaves, F., Gray, J., .. Smith, M. D. (2016). Underappreciated problems of low replication in ecological field studies. Ecology, 9710), 2554-2561. DOl: 10.1002/ecy.1506

López,..C. G., \& Kraus, F. B. (2009). Cherchezla femme? Site choice of drone congregations in the stingless bee Scaptotrigona mexicana. Animal Behaviour, 77, 1247-1252. DOl: 10.1016/j.anbehav.2009.01.034

Meirmans, P. G., \& Van Tienderen, P. H. (2004). GENOTYPE and GENODIVE: two programs for the analysis of genetic diversity of asexual organisms. Molecular Ecology Notes, 4, 792-794. DOl: 10.1111/j.1471-8286.2004.00770.x

Michalakis, Y., \& Excoffier, L. (1996). A generic estimation of population subdivision using distances between alleles with special reference for microsatellite loci. Genetics, 142, 1061-1064. DOI: 10.1093/genetics/142.3.1061

Michener, C. D. (2013). The Meliponini. In Pot-honey (pp. 3-17). New York: Springer. DOl: 10.1007/978-14614-4960-7_1

Moilanen, A., Sundström, L., Pedersen, J. (2004). 
MATESOFT: a program for deducing parental genotypes and estimating mating system statistics in haplodiploid species. Molecular Ecology Notes, 4, 795-797.

Moritz, C. (2002). Strategies to protect biological diversity and the evolutionary processes that sustain it. Systematic Biology, 57(2), 238-254. DOl: 10.1080/10635150252899752

Mueller, M. Y., Moritz, R. F. A., Kraus, F. B. (2012). Outbreeding and lack of temporal genetic structure in a drone congregation of the neotropical stingless bee Scaptotrigona mexicana. Ecology and Evolution, 2(6), 1304-1311. DOl: 10.1002/ece3.203

Oldroyd, B. P., Smolenski, A. J., Cornuet, J. M., Wongsiri, S., Estoup, A., Rinderer, T. E., Crozier, R. H. (1996). Levels of polyandry and intracolonial genetic relationships in Apis dorsata (Hymenoptera: Apidae). Annals of the Entomological Society of America, 89(2), 276283. DOl: 10.1093/aesa/89.2.276

Palmer, K. A., Oldroyd, B. P., Quezada-Euán, J. J. G., Paxton, R. J., May-ltza, W. D. J. (2002). Paternity frequency and maternity of males in some stingless bee species. Molecular Ecology, 17(10), 2107-2113. DOl: 10.1046/j.1365-294X.2002.01589.x

Paxton, R. J. (2000). Genetic structure of colonies and a male aggregation in the stingless bee Scaptotrigona postica, as revealed by microsatellite analysis, Insectes Sociaux, 471), 63-69. DOl: $10.1007 / s 000400050010$

Paxton, R. J., Weißschuh, N., Engels, W., Hartfelder, K., Quezada-Euan, J. J. G. (1999a). Not only single mating in stingless bees. Naturwissenschaften, 86, 143146. DOl: 10.1007/s001140050588

Paxton, R. J., Weissschuh, N., Quezada-Euan, J. J. G. (1999b). Characterization of dinucleotide microsatellite loci for stingless bees. Molecular Ecology, 8(4), 690-692. DOl: 10.1046/j.1365294x.1999.00874.x

Peters, J. M., Queller, D. C., Imperatriz-Fonseca, V. L., Roubik, D. W., Strassmann, J. E. (1999). Mate number, kin selection and social conflicts in stingless bees and honeybees. Proceedings of the Royal Society B: Biological Sciences, 266(1417), 379-384. DOl: 10.1098/rspb.1999.0648

Quezada-Euán, J. J. G. (2018). The Past, present, and future of meliponiculture in Mexico. In Stingless Bees of Mexico (pp. 243-269): Springer. DOl: 10.1007/9783-319-77785-6_9

Quezada-Euán, J. J. G., de Jesús May-ltzá, W., González-Acereto, J. A. (2001). Meliponiculture in Mexico: problems and perspective for development. Bee World, 82(4), 160-167. DOl: 10.1080/0005772X.2001.11099523

Ryman, N., \& Palm, S. (2006). POWSIM: a computer program for assessing statistical power when testing for genetic differentiation. Molecular Ecology Notes, 6(3), 600-602. D0l: 10.1111/j.14718286.2006.01378.x

Sánchez, D., Solórzano-Gordillo, E., Vandame, R. (2016). A study on intraspecific resource partitioning in the stingless bee Scaptotrigona mexicana Guérin (Apidae, Meliponini) using behavioral and molecular techniques. Neotropical Entomology, 45(5), 518523. DOl: 10.1007/s13744-016-0404-2

Sánchez-Guillén, D., Vandame, R., Kraus, F. B. (2018). Genetic analysis of wild drone congregations of the stingless bee Scaptotrigona mexicana (Hymenoptera: Apidae) reveals a high number of colonies in a natural protected area in Southern Mexico. Revista Mexicana de Biodiversidad, 89(1), 226-231.DOl: 10.22201/ib.20078706e.2018.1.2105

Schlüns, H., Moritz, R. F. A., Neumann, P., Kryger, P." Koeniger, G. (2005). Multiple nuptial flights, sperm transfer and the evolution of extreme polyandry in honeybee queens. Animal Behaviour, 70(1), 125-131. DOl: 10.1016/j.anbehav.2004.11.005

Schuelke, M. (2000). An economic method for the fluorescent labeling of PCR fragments. Nature Biotechnology, 18(2), 233-234. DOl: 10.1038/72708

Simone-Finstrom, M., Walz, M., Tarpy, D. R. (2016). 


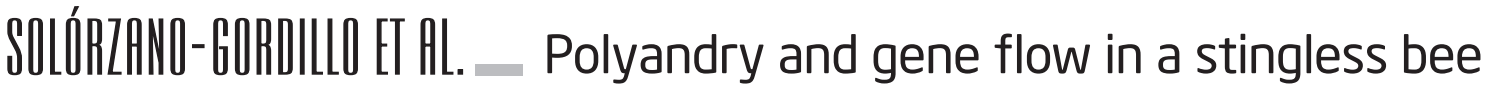

Genetic diversity confers colony-level benefits due to individual immunity. Biology Letters, 12(3), 20151007. DOl: 10.1098/rsbl.2015.1007

Solórzano-Gordillo, E., Cabrera-Marín, N., Mérida, J., Vandame, R., Sánchez, D. (2015). Diversidad genética de dos especies de abejas sin aguijón, Trigona nigerrima (Cresson) y Trigona corvina (Cockerell) en paisajes cafetaleros del Sureste de México. Paper presented at the IX Congreso Mesoamericano sobre Abejas Nativas, San Cristóbal de las Casas, Chiapas, México.

Sommeijer, M. J., \& de Bruijn, L. L. M. d. (1995). Drone congregations apart from the nest in Melipona favosa. Insectes Sociaux, 42(2), 123-127.

Starr, C. K. (1984). Sperm competition, kinship, and sociality in the aculeata Hymenoptera. In Sperm Competition and the Evolution of Animal Mating Systems (pp. 427-464). New York: Academic Press.

Tarpy, D. R., \& Page Jr, R. E. (2001). The curious promiscuity of queen honey bees (Apis mellifera): evolutionary and behavioral mechanisms. Annales Zoologici Fennici, 38, 255-265.

Truett, G., Heeger, P., Mynatt, R., Truett, A., Walker, J., Warman, M. (2000). Preparation of PCR-quality mouse genomic DNA with hot sodium hydroxide and tris (HotSHOT). Biotechniques, 29(1), 52-54. DOl: 10.2144/00291bm09

Veiga, J. C., Ruiz, G. R. S., Carvalho-Zilse, G. A., Menezes, C., Contrera, F. A. L. (2021). Queens remate despite traumatic mating in stingless bees. Current Zoology.

Viana, M. V. C., de Carvalho, C. A. L., Sousa, H. A. C., Francisco, A. K., Waldschmidt, A. M. (2015). Mating frequency and maternity of males in Melipona mondury (Hymenoptera: Apidae). Insectes Sociaux, 62(4), 491-495.
Vollet-Neto, A., dos Santos, C. F., Santiago, L. R., de Araujo Alves, D., de Figueiredo, J. P., Nanzer, M., ... Imperatriz-Fonseca, V. L. (2015). Diploid males of Scaptotrigona depilis are able to join reproductive aggregations (Apidae, Meliponini). Journal of Hymenoptera Research, 45, 125-130. D0l: 10.3897/ JHR.45.4769

Vollet-Neto, A., Imperatriz-Fonseca, V. L., Ratnieks, F. L. W. (2019). Queen execution, diploid males, and selection for and against polyandry in the Brazilian stingless bee Scaptotrigona depilis. The American Naturalist, 194(5), 725-735.

Vollet-Neto, A., Koffler, S., dos Santos, C. F., Menezes, C., Nunes, F. M. F., Hartfelder, K., ... Alves, D. A. (2018). Recent advances in reproductive biology of stingless bees. Insectes Sociaux, 65(2), 201-212.

Whitehorn, P. R., Tinsley, M. C., Goulson, D. (2009). Kin recognition and inbreeding reluctance in bumblebees. Apidologie, 40,627-633. DOl.:. 10.1051/ apido/2009050

Wille, A. (1983). Biology of the stingless bees. Annual Review of Entomology, 28(1), 41-64. D0l: 10.1146/ annurev.en.28.010183.000353 


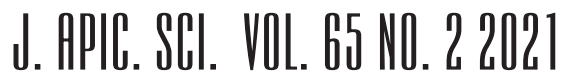

supplementary material 1

supplementary material 2

supplementary material 3 